\title{
Wiedza i światło u Jana Amosa Komeńskiego w Labiryncie świata i raju serca i w twórczości Fiodora Dostojewskiego - podobieństwa i różnice
}

\author{
Knowledge and light - Labyrinth of the World and Paradise of the Heart \\ by John Amos Comenius and the works by Fyodor Dostoyevsky \\ - similarities and differences
}

DOI: $10.34739 /$ szk.2021.08.11

\begin{abstract}
Streszczenie: W dziełach Jana Amosa Komeńskiego (1592-1670) światło częstokrotnie odgrywa kluczową rolę przy interpretacji tekstu. Ma to związek z filozofią baroku, według której człowiek błądzi po metaforycznym labiryncie życia, a dopiero później, przechodząc przez mrok, może dotrzeć do prawdy. Światło w utworach Komeńskiego jest szczególnie istotne dla poznania, któremu Jan Amos Komeński poświęcił dużą część swojej twórczości, zarówno artystycznej, jak i pedagogicznej. Fiodor Dostojewski (1821-1881) w swoich rozważaniach nad naturą człowieka i Boga również odnosi się do interpretacji biblijnej, według której światło jest ściśle związane z obecnością Chrystusa. Człowiek jest postawiony przed wyborem pomiędzy światłem a ciemnością, jest zagubiony w wyborze niczym w barokowym świecie-labiryncie i mroku. Słowa kluczowe: Światło, Komeński, labirynt, Dostojewski, Chrystus, człowiek, Bóg
\end{abstract}

Abstract: In the works by John Amos Comenius (1592-1670), light often plays a key role in the interpretation of the text. This is related to the philosophy of the Baroque, according to which a person wanders through the metaphorical labyrinth of life and only later, passing through the darkness, can reach the truth. Light in Comenius' works is particularly important for cognition, to which John Amos Comenius devoted a large part of his work, both artistic and pedagogical. Fyodor Dostoyevsky (1821-1881) in his reflections on the nature of man and God also refers to the biblical interpretation according to which light is closely related to the presence of Christ. Man is faced with a choice between the light and the dark, he is lost in the choice, as if in a baroque world-maze and darkness.

Keywords: Light, Comenius, labyrinth, Dostoevsky, Christ, man, God

Kultura i myślenie barokowe, żywiołowe, emocjonalne, stojące w opozycji do harmonijnego i antropocentrycznego renesansu, zwróciło się ku Bogu. Nurt dionizyjski, który po wielu latach po Friedrichu Nietzschem rozwinął 
Julian Krzyżanowski, rozciągając je na epoki literackie, tym samym tworząc sinusoidę epok, wyjątkowo mocno akcentował związki człowieka z siłą wyższą, w pewnym sensie będąc nurtem aintelektualnym. Motyw światła - „Bóg jest światłością i my mamy żyć w światłości”, jak głosi Ewangelia św. Jana (1J 1,5-2,2) - jest szczególnie ważny dla baroku właśnie przez związki z Bogiem. I chociaż na pierwszy rzut oka motyw światła może odwoływać się wyłącznie do dobra, jasności, to należy pamiętać, że sama istota Boga, czyli światłości per se, jest nierozerwalnie związana z tajemnicą, czymś, czego człowiek przez swoją naturę nie jest w stanie pojąć (Laskowski, 2016: 67). Dlatego właśnie motyw światła jest wyjątkowo mocno eksponowany w twórczości Jana Amosa Komeńskiego, często stawianego za wzór twórczości i filozofii baroku. W późniejszych latach motyw światła ewoluował, aż znalazł swoją reinterpretację w dziełach Fiodora Dostojewskiego, który, łącząc go z prawosławiem, stworzył nowe spojrzenie na światło w swojej istocie. Celem tego artykułu jest przedstawienie licznych podobieństw w sposobie ukazywania światła w pracach Jana Amosa Komeńskiego oraz Fiodora Dostojewskiego, a także wyróżnienie najistotniejszych różnic, które tworzą światopoglądy wspomnianych autorów.

Barokowa interpretacja światła, a zwłaszcza Jana Amosa Komeńskiego w utworze Labirynt świata i raj serca, wyraźnie koresponduje z interpretacją biblijną - „Słowo Twoje, Panie, jest pochodnią dla stóp moich i światłem na mojej ścieżce" (Ps 119, 105). Światło jest oczywiście przeciwstawione ciemności, daje nadzieję, lecz jest również silnie związane z Bogiem. Nie może to dziwić, jeżeli weźmie się pod uwagę życiorys czeskiego pedagoga - był duchownym we wspólnocie braci czeskich, protestanckim reformatorem i myślicielem. Pismo Święte było dla niego autorytetem, nieprzekraczalną granicą podczas prac nad tekstami o tematyce światopoglądowej czy pedagogicznej. Dzisiaj, gdy nauka opiera się na dowodach naukowych, znacząco utrudniłoby to pracę Komeńskiemu. (Grzegorczyk, 2017: 174). Pomimo niewątpliwego uniwersalizmu jego dzieł (można tu wymienić twórczość związaną z religią, filozofią, wspomnianą pedagogiką i polityką), są one naznaczone silnym duchem swoich czasów (Sitarska, 2007: 77). Wpływ myślenia barokowego na twórczość Jana Amosa Komeńskiego przejawia się nie tylko w motywie labiryntu, ukazującym życie człowieka jako ciągłe błądzenie po korytarzach losu czy właśnie poszukiwaniu prawdy (w o wiele większym stopniu przedmiotowi poszukiwań Komeńskiego odpowiada rosyjskie słowo истина; ma ona wieczny charakter, nie jest zależna od człowieka, jest absolutna) przez mrok znaczy to dokładnie tyle, że prawda znajduje się w świetle, jest z nim właściwie utożsamiana, tak jak ma to miejsce w chrześcijańskim ujęciu. 
Labirynt świata i raj serca, czyli jeden z najważniejszych tekstów artystycznych Jana Amosa Komeńskiego, jest wyrażeniem par excellence filozofii baroku. Zwraca na to uwagę Ravkin, który uważa, że Labirynt świata i raj serca jest kluczem metodologicznym do poglądów społeczno-estetycznych Jana Amosa Komeńskiego (Ravkin, 1992: 81). Pielgrzym podróżuje po świecie, analizuje każdy aspekt życia człowieka: od rzemieślnictwa, edukacji po filozofię, tym samym odkrywając, badając i porównując zastane zjawiska. Podkreśla to również Werner Korthaase, mówiąc, że myśl Komeńskiego jest globalna, w pewnym sensie całościowa, a nie jedynie europejska (Марчукова, 2009: 84). Potwierdza to podróż Pielgrzyma, która obejmuje całe miasto, a nie jego fragment. Towarzyszą mu przewodnicy (a więc nie jest to podróż chaotyczna, lecz kontrolowana przez Pielgrzyma). Podobnie człowiek w barokowej koncepcji nie jest opuszczony w bezładzie świata, a po prostu nie ma na wszystko wpływu, można tu wymienić znamienne Omamienie.

Drogę Pielgrzyma można porównać z ornamentem. Z początku patrzy na miasto z daleka, z wieży, podziwiając ornament jako całość, widzi „rozliczne stany", czyli drobne elementy, składające się na ozdobny ornament. W pewnym momencie wydaje mu się, że ulice są rozerwane, można się na nich zgubić, co wyraźnie odsyła nas do motywu labiryntu, obecnego także w barokowych ornamentach. Ozdobna całość jest następnie poznawana od wewnątrz; Pielgrzym zbliża się do każdego elementu, na końcu docierając do Mądrości. Jednak należy zadać sobie pytanie, czy rzeczywiście dociera do celu swojej wędrówki? Na ile jest to ułuda, labirynt, pewnego rodzaju mrok, przez który musi przejść człowiek, aby dotrzeć do prawdy?

Prawdziwą światłością w Labiryncie świata i raju serca jest Chrystus: „A w tej światłości spuściła się do mnie jakaś postać jasna, nam ludziom podobna, lecz takiej światłości, jak tylko sam Bóg” (Komeński 1914: 128). Dopiero dzięki boskiej pomocy Pielgrzym jest w stanie „przeciwstawić się” ułudzie, Omamieniu czy fałszywej Mądrości. Interpretacja światła według Jana Amosa Komeńskiego ma bez wątpienia charakter epistemologiczny (episteme - wiedza, dotyczy więc głównego przedmiotu zainteresowań Komeńskiego). Prawdziwe poznanie świata takiego, jakim jest naprawdę, umiejętność pewnej redukcji tego, co nieistotne, jest możliwe wyłącznie z Chrystusem. Wiara pozwala doceniać piękno stworzenia boskiego. Jest to koncepcja oczywiście spójna z pedagogicznymi poglądami Komeńskiego, według których tylko Bóg jest przedmiotem wiedzy, ale z racji tego, że jest dla nas niepoznawalny (stąd wcześniejszy paradoks tajemnicy światła), musimy skoncentrować się na poznawaniu świata, czyli dzieła Bożego, człowieka i Pisma Świętego (Sitarska, 2014: 359). Te trzy aspekty można sprowadzić do pozyskiwania wiedzy, dla- 
tego tak ważny jest aspekt edukacji w twórczości Komeńskiego. Przywiązywał on wagę do wykształcenia, wychowania, dzięki któremu człowiek może dążyć do pełni poznania, które jednak jest niemożliwe do rzeczywistego osiągnięcia - ogranicza je omnes, omnia, omnino - wszyscy, wszystko, całkowicie (doskonale) (Bieńkowski, 2000: 90). Czy człowiek (za pomocą ziemskich sposobów) może objąć swoim rozumem wszystkich, wszystko i całkowicie? Jan Amos Komeński był pewien, że nie. Możliwość poznania „całości” daje jedynie interwencja boska: „Tak tedy widziałem blask, jasność, chwałę i sławę, której język ludzki wysłowić nie zdoła i huk niewymowny, także słyszałem" (Komeński, 1914: 137). Z jej pomocą człowiek odrzuca fałsz czy działania pozbawione znaczenia (niech za przykład posłuży nauka języków obcych, gdy nie idzie za nią mądrość) (Komeński, 1914: 20-21). Widzimy tutaj pewną ciągłość intelektualną między Komeńskim a wcześniejszym myślicielem Augustynem z Hippony, według którego do prawdziwego poznania niezbędny jest akt oświecenia (konieczność illuminatio, gdyż ciało nie ma możliwości poznania duszy). W Labiryncie świata i raju serca Pielgrzym doświadcza oświecenia sensu stricto, ponieważ jest w stanie nie tylko zobaczyć niewidzialny kościół (tytuł rozdziału trzydziestego siódmego, Pielgrzym do niewidzialnego kościoła idzie, czyli niedostępnego zwykłemu człowiekowi, ograniczonemu przez swój wzrok, zmysły), ale również ukazuje mu się tron Starodawnego oraz Chrystus, z którym Pielgrzym rozmawia. Interwencja boska pozwala Pielgrzymowi na nowo poznać otaczający go świat, co sam wyznaje na ostatnich stronach Labiryntu świata i raju serca: „Błądziłem po świecie; Tyś mię upamiętał. Byłem w obłędzie, nie wiedząc, gdzie iść; Tyś mię na prawą drogę zaprowadził. Zaszedłem od Ciebie, i siebie i Ciebie gdzieś zagubiłem" (Komeński, 1914: 139). Początkowo Pielgrzym starał się poznać świat za pomocą ziemskich sposobów, zmysłów czy umysłu, które jednak zawiodły, ponieważ dopiero z przyjściem Chrystusa (czyli postaci niebiańskiej, pozarozumowej) można zbliżyć się do prawdy, a nawet do niej dotrzeć. Próbą dotarcia do omnes, omnia, omnimo jest właśnie Labirynt świata i raj serca, który należy odczytywać jako prolog do pansofii, obecnej w późniejszych pracach Jana Amosa Komeńskiego (przede wszystkim Schola pansophia) (Марчукова, 2009: 85). Salomon, czyli ucieleśnienie ziemskiej mądrości (ziemskiej, więc „niepełnej”), potrafi przeciwstawić się fałszywej Mądrości, zerwać pajęczynę z twarzy Królowej, jednak nie jest w stanie oprzeć się ziemskim żądzom, na przykład Rozkoszy, tym samym daje się wprowadzić „między zwierzęta; i rozliczne płazy, smoki i węże jadowite, i z tymi smutną zabawę rozpoczął” (Komeński, 1914: 122). Salomon, prorok i „wielki budowniczy”, jest w stanie doprowadzić człowieka jedynie do pewnej granicy, wytyczonej przez ludzką naturę. Pełnię poznania 
o otaczającej nas rzeczywistości daje dopiero zejście Chrystusa, zapowiedź pansofii, które jest ściśle powiązane z motywem światła w twórczości Komeńskiego. Potrzebę dążenia do całości, wszechstronnego nauczania uniwersaliów, Jan Amos Komeński podkreślał w swoich pracach pedagogicznych.

Należy wspomnieć o jeszcze innym dziele Komeńskiego wprost nawiązującego do światła jako drogi umożliwiającej człowiekowi rozwój i poznanie prawdy: Via lucis, proponującym reformę życia zarówno politycznego, jak i kulturalnego, dzięki której właśnie wiedza i wykształcenie, czyli jedne z najbardziej nurtujących Jana Amosa Komeńskiego zagadnień, miałyby być drogą do poznania świata. Światło ponownie należy interpretować w wymiarze epistemologicznym, jako drogę do poznania świata, Boga, sztuki czy ludzi. „Rozumienie harmonii rzeczywistości, wzajemnego stosunku wszystkich do rzeczy wszystkich innych jest dopiero tym, co dostarcza zmysłom jasnego światła" (Bieńkowski 2000: 88-93), dlatego to właśnie wykształcenie było dla Komeńskiego tak bardzo istotne; dawało możliwość metaforycznego „oświecenia" ludzkości, bez względu na ich rozwój fizyczny czy intelektualny, dla Komeńskiego stało się podstawą pedagogiki specjalnej (Natora, 2014: 240).

Motyw światła na przestrzeni wieków bardzo często pojawiał się w literaturze, zwłaszcza tej nawiązującej do tematyki religijnej. Dla naszych rozważań wyjątkowo ważna będzie twórczość Fiodora Dostojewskiego, która łączyła w sobie - podobnie jak twórczość Jana Amosa Komeńskiego - elementy filozofii, teologii, czy, co wydaje się oczywiste, literatury.

Jednym z kluczowych tekstów Dostojewskiego, w którym pojawia się motyw światła, jest Zbrodnia i kara. Dzieło samo w sobie stanowi pewien punkt przejścia, granicę, która została zasygnalizowana już w tytule. W całym utworze wielokrotnie mamy do czynienia z momentami przejścia; dość wymienić pięciokrotnie zachodzące słońce (moment granicy pomiędzy dniem a nocą) (Jankowska, 2013: 47-50): łącząc w sobie znaczenie tego, co powinno być odrzucone (...) zachód słońca jest kolejnym określeniem wskazującym na negatywne skojarzenia (Ryken, 2003: 1143). Niech za kolejny przykład posłuży rozmowa Lizawiety z kupcami, którą usłyszał Raskolnikow „około dziewiątej”, gdy handlarze zamykali już swoje stragany. Moment graniczny, który sprawił, że ,jego początkowe zaskoczenie stopniowo ustępowało miejsca zgrozie; skóra mu cierpła" (Dostojewski, 1971: 77), a więc przybliżył się, właściwie podjął decyzję o zamordowaniu starej lichwiarki, o przekroczeniu kolejnej granicy, sprawdzeniu siły woli w dążeniu do miana nadczłowieka avant la lettre.

Symbolika światła pojawia się również w innych utworach Dostojewskiego, w tym fundamentalnych dla zrozumienia filozofii rosyjskiego pisarza Braciach Karamazow. Wspomnienia Aloszy o swojej matce, jurodiwej (szalo- 
nej w Chrystusie, która, paradoksalnie, błądząc w szaleństwie i mroku na ziemi, jest według prawosławnej tradycji bliższa Bogu, czyli niebiańskiemu światłu), wiążą się ze światłem z innego świata, czymś ponownie właściwym Bogu (Jewdokimow, 2006: 105-106). I chociaż Kościół prawosławny definiuje światło Chrystusa, światło Przeobrażenia jako wcielenie Bożych energii (Kotielnikow, 2002: 286), to u Dostojewskiego światło ma zgoła inny charakter. Gdy światło u Jana Amosa Komeńskiego, jak już było wspomniane, nosi charakter epistemologiczny, pozwala dostrzec prawdziwą naturę otaczającego nas świata, zbliżyć się do omnes, omnia, omnino, tak u rosyjskiego pisarza, chociaż ponownie związane z Bogiem, światło powinno być odczytywane w wymiarze egzystencjalnym. W pewnym stopniu pojawienie się światła (na przykład przebudzenie się Raskolnikowa po morderstwie) bądź jego zniknięcie zwiastuje nam pewne wydarzenia lub odsyła do rozterek bohaterów, wokół których światło pojawia się czy znika.

Należy jednak sobie zadać pytanie, czy Dostojewski w tym samym stopniu ukazuje Chrystusa jako zbawiciela, który przyjdzie człowiekowi z pomocą, jak to miało miejsce w Labiryncie świata i raju serca? Czy wątpi w jego sprawczość na ziemi?

„W moim pokoju przed obrazem zapala się zawsze na noc lampkę światło jest blade i nikłe, wszystko jednak można przy nim rozpoznać, a pod samą lampką można nawet czytać" - właśnie w ten sposób funkcjonuje Bóg w utworach Dostojewskiego (Dostojewski, Idiota 1979: 458). Pojawia się jedynie z boku, w ludzkich odruchach, jak gdyby nie mógł w pełni rozgonić mroku (Michałowski, 2015: 15), wskazuje na miejsce, w którym się pojawia, jednak nie interweniuje w sposób właściwy dla illuminatio. Człowiek ma za zadanie sam przezwyciężyć mrok, który go otacza, a nie z pomocą Chrystusa czy po jego przyjściu. To znacząca zmiana punktu ciężkości - na człowieku spoczywa odpowiedzialność; światło jedynie stawia w sytuacji wyboru, a nie go dokonuje. Utwory Dostojewskiego, w większości ukazujące jedynie opozycję światłość - ciemność (zwłaszcza Notatki z podziemia), są jednak poświęcone światłu. „W jaki sposób jasna strona obrazu będzie widoczna, jeśli nie będzie ciemnej? (...) Pojęcie o świetle mamy tylko dlatego, że istnieje ciemność" (Dostojewski, Listy 1979: 69).

Dostojewski korzysta z kontrastu, tworząc związanych ze światłem bohaterów - prostytutka Sonia Marmieładowa, chory psychicznie książę Myszkin, piętno żądzy w rodzinie Aloszy Karamazowa - co jedynie podkreśla ich wręcz zbawczy charakter. Przedstawiani są jako ziemskie światło, które nie służy do poznania pełni rzeczywistości (w wymiarze pedagogicznym czy jakimkolwiek innym), a jedynie do nakierowania na właściwą ścieżkę. Dlatego właśnie światło u Dostojewskiego nie ma absolutnej wartości, często jest 
kwestionowane, czy to przez Raskolnikowa, Rogożyna, Iwana Karamazowa, czy nawet przez samego Aloszę, postać-światło, który sam odchodzi z monastyru, zbliża się do mroku. Oczywiście, teksty Dostojewskiego są chrystocentryczne, można je odczytywać w kluczu chrześcijańskim, a ściślej prawosławnym, ale czy Chrystus jest jedynym „obowiązującym światłem”? (Michałowski, 2015: 14). Na kartach powieści Dostojewskiego poglądy dotyczące diabła, ciemności są wyrażane w równie zdecydowany sposób, co poglądy spod znaku światła. Każdy ruch Chrystusa, wyrażony głosami bohaterów, jest naznaczony mrokiem diabła, który nieustająco kusi bohaterów, w pełni wyrażając swoje poglądy dzięki polifonicznej strukturze tekstu. Podkreśla to tylko egzystencjalny charakter światła w utworach Dostojewskiego - bohaterowie są nie tylko postawieni w sytuacji wyboru, ale również rozdarci pomiędzy obiema skrajnościami, wzajemnie wykluczającymi się.

„Tu diabeł z Bogiem się zmaga, a polem bitwy jest serce człowiecze” (Dostojewski, 1984: 133) - te słowa mogą podsumować filozofię Dostojewskiego, która przede wszystkim zwraca uwagę na człowieka, jego decyzje, myśli, a nie na to, co się wokół niego dzieje. Człowiek jest odpowiedzialny za wybór pomiędzy światłem a ciemnością, jednak ta odpowiedzialność nie oznacza samotności. Chrystus jest obecny obok, wcielony Chrystus, Bógczłowiek, który przychodzi dopiero po otwarciu się człowieka na niego. Jak już było podkreślone, nie jest to interwencja Chrystusa, która ratuje człowieka - to dusza musi się otworzyć na Boga, aby ten zstąpił do piekieł ludzkiej duszy (czyli dotychczas pozbawionej Boga, miłości) (Michalska-Suchanek, 2014: 311-312). To człowiek musi wykonać pierwszy krok, podjąć decyzję Chrystus w twórczości Dostojewskiego daje człowiekowi prawdziwą wolność: pozwala zmartwychwstać bądź upaść. Prawdziwe światło mogło zaistnieć dopiero po upadku człowieka, doświadczeniu mroku. Odpowiedzialność człowieka polega na tym, że sam musi zwrócić się w stronę Boga, w pewnym sensie zrozumieć swój grzech, a dopiero wtedy Chrystus, w postaci światła, będzie w stanie mu pomóc.

Jan Amos Komeński i Fiodor Dostojewski przedstawiali światło w wielu swoich utworach. Niewątpliwie łączył ich wpływ barokowego myślenia, zanurzenie człowieka w mroku, w którym ten musiał odnaleźć prawdę. Zadaniem człowieka było dotarcie do światła, przeciwstawienie się ciemności, lecz i Komeński, i Dostojewski zupełnie inaczej pojmowali istotę światła. Dla czeskiego myśliciela i pedagoga światło było związane z Chrystusem, który może się objawić (niczym u Augustyna z Hippony i jego illuminatio), a następnie wyciągnąć pomocną dłoń. Szczególny wyraz takiemu poglądowi Jan Amos Komeński dał w Labiryncie świata i raju serca, gdzie Pielgrzym dopiero po interwencji Chrystusa jest w stanie dostrzec piękno Bożego dzieła, co wska- 
zuje nam na ścisły związek światła z epistemologią. Zgoła odmienny stosunek do światła możemy zauważyć u Fiodora Dostojewskiego. Dla rosyjskiego pisarza światło, co wydaje się oczywiste, również jest związane z Chrystusem, jednak funkcjonuje ono nieco z boku. Nie przychodzi z pomocą człowiekowi, lecz stawia go przed wyborem. Dopiero gdy człowiek zauważy w swojej duszy brak Boga, Chrystus (wraz ze światłem) jest w stanie zstąpić do piekładuszy i odkupić jego grzechy. Światło u Fiodora Dostojewskiego należy interpretować w wymiarze egzystencjalnym, które stawia człowieka przed wyborem - kluczowym dla dalszego życia - pomiędzy światłem a ciemnością. Idea, którą wyraził Jan Amos Komeński w Labiryncie świata i raju serca, jak i w całej swojej twórczości, była szczególnie ważna dla rozwoju pedagogiki w Europie (czy nawet na całym Zachodzie). Wprowadzenie nowego i jednolitego systemu szkolnictwa, zwrócenie uwagi na kwestie organizacyjne w edukacji czy odejście od dyskryminującej postawy przy przyjmowaniu do szkół - kwestie takie jak płeć, miejsce zamieszkania, a także rozwój fizyczny i intelektualny przestały być ważne, czym dał podwaliny pod rozwój pedagogiki specjalnej - to tylko niektóre z zasług czeskiego pedagoga. Twórczość obu autorów jest reprezentatywna dla tendencji, myśli swoich czasów, dlatego tak ważne jest dalsze badanie ich utworów. Dodatkowo dzieła Dostojewskiego charakteryzują się również silnymi związkami z estetyką i filozofią baroku, więc podobieństwa między Janem Amosem Komeńskim a Fiodorem Dostojewskim w przyszłości na pewno zostaną odkryte i należycie przebadane.

\section{Bibliografia}

Bieńkowski Tadeusz, Jan Amos Komeński o nauczaniu i wychowaniu, Pułtusk 2000.

Dostojewski Fiodor, Bracia Karamazow, przeł. Aleksander Wat, Warszawa 1984.

Dostojewski Fiodor, Idiota, przeł. Jerzy Jędrzejewicz, Warszawa 1979.

Dostojewski Fiodor, Listy, przeł. Zbigniew Podgórzec, Ryszard Przybylski, Warszawa 1979.

Dostojewski Fiodor, Zbrodnia i kara, przeł. Czesław Jastrzębiec-Kozłowski, Warszawa 1971.

Grzegorczyk Barbara, Gdyby Jan Amos Komeński żył współcześnie..., w: B. Sitarska (red.), Współczesne recepcje Jana Amosa Komeńskiego, „Siedleckie Zeszyty Komeniologiczne, seria pedagogika" 2017, t. IV, s. 165-176.

Jankowska Tatiana, $O$ wzajemnych relacjach kategorii przestrzeni i postaci $w$ tekście miasta Charlesa Dickensa i Fiodora Dostojewskiego, „Przegląd Rusycystyczny” 2013, nr 3, s. 45-56.

Jewdokimow Dorota, Sofijność w twórczości filozoficznej i literackiej Fiodora Dostojewskiego, „IDEA. Studia nad strukturą i rozwojem pojęć filozoficznych” 2006, t. XVIII, s. 93-107.

Komeński Jan Amos, Labirynt świata i raj serca, przeł. Jan Pindór, Cieszyn 1914. 
Kotielnikow Władimir, Prawosławnyje podwiżniki, Moskwa 2002, s. 286.

Laskowski Łukasz, Symbolika światła w literaturze dydaktycznej Starego Testamentu, „Verbum Vitae” 2016, nr 29, s. 67-98.

Марчукова Светлана Марковна, «Лабиринт света и рай сердца» Я.А. Коменского и современная педагогика, «Известия Российского государственного педагогического университета им. А.И. Герцена» 2009, № 102, с. 83-93.

Michalska-Suchanek Mirosława, Poprzez mrok i piekło. Soteriologia prawosławna według Fiodora Dostojewskiego, „Wschodni Rocznik Humanistyczny” 2014, t. X, s. 307-316.

Michałkowski Damian, Ambiwalencja i Tajemnica. Wokół antropologii filozoficznej Dostojewskiego, „Logos i Ethos” 2015, nr 38, s. 7-24.

Natora Halina, Jan Amos Komeński - prekursor pedagogiki specjalnej, w: B. Sitarska (red.), O Janie Amosie Komeńskim i jego poglądach na edukację, „Siedleckie Zeszyty Komeniologiczne, seria pedagogika" 2014, t. I, s. 239-247.

Равкин Захар Ильич, Великий реформатор школы. К 400-летию со дня рождения Я.А. Коменского, „Педагогика” 1992, № 5-6, с. 81-85.

Ryken Leland, Słownik symboliki biblijnej, Warszawa 2003.

Sitarska Barbara, Jan Amos Komeński prekursorem idei edukacji całożyciowej, w: B. Sitarska, R. Mnich (red.), Jan Amos Komeński a kultura epoki baroku /Johan Amos Comeniusund die Kultur des Barock, „Studia Comeniana Sedlcensia”, t. I, Siedlce 2007, s. 71-82.

Sitarska Barbara, Labirynty Jana Amosa Komeńskiego i drogi prowadzące do uniwersalnej światłości, w: B. Sitarska (red.), O Janie Amosie Komeńskim i jego pogladach na edukacje, „Siedleckie Zeszyty Komeniologiczne, seria pedagogika” 2014 , t. I, s. $349-370$. 